\title{
IDENTIFIKASI SENYAWA METABOLIT SEKUNDER EKSTRAK n-HEKSANA BATANG KESEMBUKAN (Paederia foetida Linn)
}

\author{
Elok Kamilah Hayati, Roihatul Muti’ah, Ifaridatul Chusna
}

Jurusan Kimia, Fakultas Sains dan Teknologi UIN Maulana Malik Ibrahim Malang

\begin{abstract}
ABSTRAK
Tanaman kesembukan (Paaderia foetida Linn) merupakan salah satu tanaman yang sering dimanfaatkan oleh masyarakat sebagai obat, sehingga dapat diketahui bahwa tanaman mempunyai aktivitas biologi, begitu juga dengan bagian batangnya. Tujuan penelitian ini adalah untuk mengetahui kandungan golongan senyawa ekstrak heksanadengan metode Kromatografi Lapis Tipis (KLT).Penelitian ini dilakukan dengan mengekstraksi sampel dengan pelarut $\mathrm{n}$-heksana.

Golongan senyawa yang terkandung dalam ekstrak klorofom diidentifikasi dengan fitokimia dengan menggunakan reagen. Pemisahan golongan senyawanya digunakan kromatografi lapis tipis (KLT).

Uji fitokimia menunjukkan ekstrak n-heksana mengandung steroid. Pemisahan dengan KLT menggunakan eluen n-heksana-etil asetat (8:2) menghasilkan 4 noda dengan nilai Rf berturut-turut 0,$10 ; 0,35$; 0,61 ; dan 0,68 .
\end{abstract}

Kata kunci: Kesembukan (Paederia foetida Linn), Artemia salina Leach, uji toksisitas, uji fitokimia.

\section{PENDAHULUAN}

Salah satu keanekaragaman tumbuhan di Indonesia adalah banyaknya tumbuhan yang dapat dimanfaatkan sebagai obat, dan salah satunya adalah tanaman Kesembukan. Kesembukan merupakan tanaman merambat di kebun-kebun ataupun lereng gunung. Kesembukan biasanya oleh masyarakat Indonesia digunakan untuk mengobati beberapa penyakit. penyakit lambung, nyeriusus, perut kembung, sariawan, encok, kurap, radang anak telinga (Mardisiswojo dan Radjakmangunsudarso, 1968).

Sejumlah senyawa golonggan steroid, terpenoid, dan 77 komponen senyawa minyak atsiri dalam daun, batang dan bunga dari tanaman Kesembukan (Paederia foetida Linn.)(Shukla, dkk. 1976 dan Wong 1994 dalam Mishra, 2012).

Nilai LC $_{50}$ ekstrak n-heksana batang Lesembukan adalah 26,6033 ppm, nilai $\mathrm{LC}_{50}$ yang kecil menunjukkan adanya senyawa aktif yang cukup aktif.

Metode pemisahan pertama dalam penelitian ini menggunakan ekstraksi maserasi. Pada penelitian ini menggunakan pelarut n-heksana, (Rita, dkk., 2008).
Pemisahan senyawa dapat dilakukan dengan kromatografi lapis tipis (KLT). Eluen sangan berpengaruh dalam pemisahan senyawa.

Oleh karena itu dilakukan identifikasi dan pemisahan kandungan senyawa aktif ekstrak heksana yang mempunyai aktifitas menggunakan kromatografi lapis tipis analitik dengan berbagai macam variasi eluen.

\section{METODE PENELITIAN \\ Pelaksanaan Penelitian}

Penelitian dilaksanakan di

Laboratorium Kimia Organik dan

Laboratorium Riset Kimia Analitik Universitas Islam Negeri Maulana Malik Ibrahim Malang pada bulan MaretsampaiJuni 2013

\section{Alat dan Bahan Penelitian}

Alat-alat yang digunakan adalah seperangkat alat gelas,rotary evaporator vaccum, tabungreaksi, lampu, kertassaring, neracaanalitik, corongbuchner, dan plat silika gel $\mathrm{F}_{254}$.

Bahan yang digunakan meliputi batang Kesembukan, n-heksana, aquades, 
reagen Dragendorff, reagen Meyer, danreagen Lieberman-Burcard.

\section{CARA KERJA}

\section{Preparasi Sampel}

Sampel tanaman Kesembukan diambil bagian batangnya, kemudian dicuci bersih, dikeringanginkan. Selanjutnya sampel dipotong kecil-kecil dan dikeringkan dengan oven pada suhu 27 - $37{ }^{\circ} \mathrm{C}$ selama $1-2$ jam. Kemudian sampel dihaluskan dengan blender sampai berbentuk serbuk dan diayak dengan ayakan 60 mesh. Hasil serbuk batang Kesembukan yang diperoleh ini digunakan sebagai sampel penelitian.

\section{Ekstraksi Senyawa Aktif dengan Maserasi \\ Serbuk batang Kesembukan} (Paederia foetida L.) ditimbang sebanyak $60 \mathrm{~g}$ dan diekstraksi dengan perendaman menggunakan $300 \mathrm{~mL}$ pelarut n-heksana selama 24 jam. Pengadukan dibantu dengan shaker, kemudian disaring dan ampasnya dimaserasi kembali dengan pelarut yang sama sampai diperoleh ampas yang pucat. Masing-masing filtrat diuapkan pelarutnya menggunakan rotary evaporator untuk mendapatkan ekstrak pekat n-heksana.

\section{Uji Fitokimia dengan Reagen}

\section{Uji Alkaloid}

Ekstrak n-heksana batang

Kesembukan sebanyak $2 \mathrm{mg}$ dimasukkan dalam tabung reaksi, ditambah $0,5 \mathrm{~mL} \mathrm{HCl}$ $2 \%$ dan larutan dibagi dalam dua tabung. Tabung I ditambahkan $0,5 \mathrm{~mL}$ reagen Dragendorff, tabung II ditambahkan 0,5 mL reagen Meyer. Jika tabung I terbentuk endapan jingga dan pada tabung II terbentuk endapan kekuning-kuningan, menunjukkan adanya alkaloid (Indrayani, dkk., 2006).

\section{Uji Flavonoid}

Ekstrak n-heksana batang Kesembukan sebanyak $2 \mathrm{mg}$ dimasukkan dalam tabung reaksi kemudian dilarutkan dalam $1-2 \mathrm{~mL}$ metanol panas $50 \%$.
Setelah itu ditambah logam $\mathrm{Mg}$ dan 0,5 mL $\mathrm{HCl}$ pekat. Larutan berwarna merah atau jingga yang terbentuk, menunjukkan adanya flavonoid (Indrayani, dkk., 2006).

\section{Uji Saponin}

Ekstrak n-heksana batang Kesembukan sebanyak $2 \mathrm{mg}$ dimasukkan dalam tabung reaksi ditambah air (1:1) sambil dikocok selama 1 menit, apabila menimbulkan busa ditambahkan 2 tetes $\mathrm{HCl} 1 \mathrm{~N}$ dan dibiarkan selama 10 menit, bila busa yang terbentuk bisa tetap stabil maka ekstrak positif mengandung saponin (Halimah, 2010).

\section{Uji Triterpenoid dan Steroid}

Ekstrak n-heksana

batang Kesembukan sebanyak $2 \mathrm{mg}$ dimasukkan dalam tabung reaksi, dilarutkan dalam 0,5 $\mathrm{mL}$ kloroform lalu ditambah dengan $0,5 \mathrm{~mL}$ asam asetat anhidrat. Campuran ini selanjutnya ditambah dengan $1-2 \mathrm{~mL}$ $\mathrm{H}_{2} \mathrm{SO}_{4}$ pekat melalui dinding tabung tersebut. Jika hasil yang diperoleh berupa cincin kecoklatan atau violet pada perbatasan dua pelarut menunjukkan adanya triterpenoid, sedangkan jika terbentuk warna hijau kebiruan menunjukkan adanya steroid (Indrayani, dkk., 2006).

\section{UjiTanin}

\section{Uji dengan LarutanFeCl 3}

Ekstrak n-heksana

batang Kesembukan sebanyak $2 \mathrm{mg}$ ditambahkan dengan $2-3$ tetes larutan $\mathrm{FeCl}_{3} 1 \%$. Jika larutan menghasilkan warna hijau kehitaman atau biru tinta, maka bahan tersebut mengandung tanin (Indrayani, dkk., 2006).

\section{Uji Tanin denganLarutan Gelatin}

Ekstrak n-heksana batang

Kesembukan sebanyak $2 \mathrm{mg}$ dimasukkan dalam tabung reaksi ditambah dengan larutan gelatin. Jika terbentuk endapan putih, menunjukkan adanya tanin (Halimah, 2010). 
Uji Tanin Katekol dan Tanin Galat

Ekstrak n-heksana batang

Kesembukan sebanyak $2 \mathrm{mg}$ ditambahkan dengan larutan formaldehid 3\%: asam klorida pekat (2:1) dan dipanaskan dalam air panas dengan suhu $90{ }^{\circ} \mathrm{C}$. Jika terbentuk endapan merah, menunjukkan adanya tanin katekol. Filtrat dijenuhkan dengan $\mathrm{Na}-$ asetat dan ditambahan larutan $\mathrm{FeCl}_{3} 1 \%$. Jika terbentuk warna biru tinta/hitam, menunjukkan adanya tanin galat (Halimah, 2010).

\section{HASIL DAN PEMBAHASAN EstraksiSenyawaAktifdenganMaserasi}

Tabel 1.Hasil maserasi ekstrak batang Kesembukan

\begin{tabular}{|c|c|}
\hline Pelarut & $\begin{array}{c}\text { Rendeman } \\
(\%)(b / b)\end{array}$ \\
\hline n-Heksana & 0,435 \\
\hline
\end{tabular}

\section{Uji Fitokimia dengan Reagen}

Uji fitokimia dalam penelitian ini dilakukan pada golongan senyawa, alkaloid, flavonoid, saponin,steroid, triterpenoid, dan tanin dengan menggunakan reagen masing-masing. Hasil uji fitokimia dengan reagen ditunjukkan pada Tabel 2

Tabel 2. Hasil identifikasi uji fitokimia ekstrak batang Kesembukan dengan Reagen.

\begin{tabular}{|l|c|}
\hline GolonganSenyawa & $\begin{array}{c}\text { Ekstrak } \\
\mathrm{n}- \\
\text { heksana }\end{array}$ \\
\hline Alkaloid & - \\
\hline Flavonoid & - \\
\hline Saponin & - \\
\hline Triter-penoid & - \\
\hline Steroid & + \\
\hline Tanin & - \\
\hline
\end{tabular}

Keterangan :

tanda + : terkandung senyawa/ warna mud tanda - : tidak terkandung senyawa/ tidak berwarna $\begin{aligned} & \text { PemisahanSenyawaAktifdenganKromato } \\ & \text { grafi Lapis Tipis (KLT) }\end{aligned}$
$\begin{array}{llr}\text { Identifikasi } & \text { dengan } & \text { KLT } \\ \text { menggunakan ekstrak } & \text { n-heksana } & \text { dengan }\end{array}$ eluen n-heksana-etilasetat (8:2) untuk memperkuat adanya senyawa steroid di bawah sinar UV $\lambda 366 \mathrm{~nm}$ ditunjukkan pada Gambar1 dan Tabel 3.
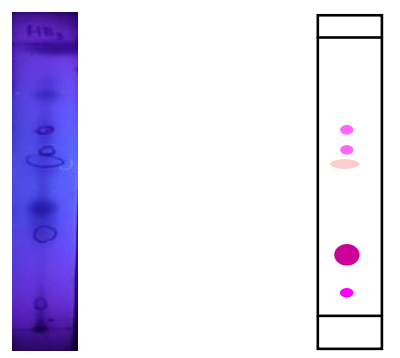

Gambar1.Hasil KLT pemisahansenyawa steroid padaekstrak n-heksanadenganeluen n-heksana-etilasetat (8:2)

Tabel 3.Hasil KLT senyawa Steroid ekstrak n-heksana batang Kesembukan eluen nheksana-etilasetat $(8: 2)$

\begin{tabular}{|c|c|c|c|}
\hline No. & $\begin{array}{c}\text { Nilai } \\
\text { Rf } \\
\text { tiap } \\
\text { noda } \\
(\mathrm{cm})\end{array}$ & $\begin{array}{c}\text { Warnanoda di } \\
\text { bawahsinarUV } \\
\lambda 366 \mathrm{~nm}\end{array}$ & $\begin{array}{c}\text { Dugaan } \\
\text { senyawa }\end{array}$ \\
\hline 1 & 0,10 & Ungumuda & Steroid \\
\hline 2 & 0,35 & Ungu & Steroid \\
\hline 3 & 0,58 & Merahmuda & - \\
\hline 4 & 0,61 & Ungumuda & Steroid \\
\hline 5 & 0,68 & Ungumuda & Steroid \\
\hline
\end{tabular}

\section{KESIMPULAN}

Berdasarkan hasil identifikasi dengan uji reagen diketahui bahwa ekstrak nheksana mengandung golongan senyawa steroid. Pemisahan dengan KLT menggunakan eluen n-heksana-etil asetat (8:2) menghasilkan 4 noda dengan nilai $\mathrm{Rf}$ berturut-turut 0,$10 ; 0,35 ; 0,61$; dan 0,68 .

\section{SARAN}

Perlu dilakukan pemisahan lebih murni dengan kromatografi kolom-KLTP dan hasil isolat yang dihasilkan diidentifikasi dengan instrumentasi MS.

\section{DAFTAR PUSTAKA}

Halimah, N. 2010. Uji Fitokimia dan Uji Toksisitas Ekstrak Tanaman AntingAnting (Acalypha indica Linn.) terhadap Larva Udang Artemia salina Leach.SkripsiDiterbitkan. Malang: 
Fakultas Sains dan Teknologi Universitas Islam Negeri Maulana Malik Ibrahim Malang.

Indrayani, L., Soetjipto, H., dan Sihasale, L. 2006. Skrining Fitokimia dan Uji Toksisitas Ekstrak Daun Pecut Kuda (Stachytarpheta jamaicensis L. Vahl) Terhadap Larva Udang Artemia salina Leach. Berk. Penel. Hayati. Vol 12, hal: $57-61$.

Mangunwardoyo, W., Cahyaningsih, E., dan Usia, T. 2009. Ekstraksi dan Identifikasi Senyawa Antimikroba Herba Meniran (Phyllanthus niruri L.). J.Ilmu Kefarmasian Indonesia. Vol. 7 No. 2, hal: 57 - 63 .

Meyer, B.N. Ferrigni, P. J.E, Jacobsen. L.B, Nichols and McLaughlin.1982. Brine Shrimp: A Convenient General
Bioassay for Active Plant Constituents.Planta Medica45: 31-34. Mishra, R. dan Bisht, S.S. 2011. Medical Values Of Skunk Vine (Paederia foetida L.) An Overview. Department of Biotechnology Roland Institute of Pharmaceutical Science, Berhampur.

Morshed, H. Islam, Md.S. Parvin, S. Uddin, M.A. Mostofa, A.G.M dan Sayyed, S.B.2012. Antimicrobial and Cytotoxuc Activity of the Methanol Extract of Peaderia foetida Linn. Journal of Applied Pharmaceitical Science. 02 (01); 2012: 77-80.

Rita, W.S., Suirta, I.W., dan Sabikin, A. 2008. Isolasi dan Identifikasi Senyawa yang Berpotensi sebagai Antitumor pada Daging Buah Pare (Momordica charantia L.). J.Kimia. Vol. 2 No. 1, hal $1-6$. 